\section{In Vitro Homeostasis of Rat Oral Epithelial Cell Cultures Following Withdrawal of Periodontal Pathogens}

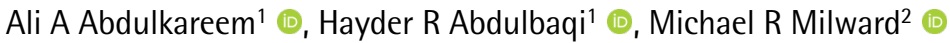

\author{
'Department of Periodontics, \\ College of Dentistry, University \\ of Baghdad, Bagdad, Iraq \\ ${ }^{2}$ Department of Periodontology, \\ School of Dentistry, University of \\ Birmingham, Birmingham, UK \\ Correspondence: Dr Ali A \\ Abdulkareem, Baghdad medical \\ city, Baghdad, lraq. Tel: +964 \\ 7806808016. email: ali.abbas@ \\ codental.uobaghdad.edu.iq
}

\begin{abstract}
Inflammation of periodontal tissues is the consequence of interaction between periodontal pathogens and immune system. This is associated with increased expression of inflammatory cytokines, which may exert destructive effect to the periodontal tissues when released over long period. The aim of this study was to chronologically track the homeostasis of oral keratinocytes following removal of periodontal pathogens. This was done by investigating expression of selected inflammatory markers and integrity of epithelial monolayers in vitro. Rat oral keratinocytes were stimulated with heat-killed Fusobacterium nucleatum and Porphyromonas gingivalis over 7-days then bacteria were washed away and epithelial cells re-cultured for 3 -days. Expression of IL-1 $\beta, I L-6$, and IL-8 was measured by ELISA while transcription of tissue inhibitor of metalloproteinase- 1 (TIMP-1) and matrix metalloproteinase-8 (MMP-8) was measured by polymerase chain reaction before and after removal of bacteria. Integrity of epithelial sheet was investigated by using transepithelial electrical resistance. Data showed general downregulation of $\mathrm{IL}-1 \beta, \mathrm{IL}-6$, and IL-8 associated with restoring transcription of TIMP-1 and MMP-8 to normal level following removal of bacteria from epithelial cultures. However, expression of IL-8 and MMP-8 remained significantly higher than unstimulated epithelial cells despite withdrawal of $F$. nucleatum and P. gingivalis respectively from oral keratinocytes cultures. In addition, integrity of epithelial barrier function remained compromised even after removal of $P$. gingivalis. Results suggest that even after three days following removal of periodontal pathogens, oral keratinocytes sustained persistent upregulation of certain inflammatory markers that could compromise integrity of epithelial barrier function.
\end{abstract}

Key Words: cytokine(s), gene expression, innate immunity, matrix metalloproteinase(s), pathogenesis of periodontal disease(s).

\section{Introduction}

Periodontitis is an inflammatory condition characterized by an irreversible destruction of tooth-supporting tissues. It is initiated and sustained by accumulation of microbial biofilm on teeth, which is aggravated by aberrant host immune responses to pathogenic bacteria in periodontal pockets (1). The gingival epithelium, in particular sulcular and junctional epithelia, acts as the major physical barrier contributing the first innate defense against invading periodontal pathogens (2). Although subgingival niche harbors vast number of bacterial species; yet, Porphyromonas gingivalis and Fusobacterium nucleatum consider as a keystone-pathogens in the initiation and progression of periodontal disease (3). Recognition of these bacteria by sulcular or junctional epithelia stimulates host epithelial cells to release series of inflammatory cytokines that recruit inflammatory cells to neutralize the invading stimuli (4).

Both $P$. gingivalis and $F$. nucleatum induce host epithelial cells to increase transcription rate of the mRNAs encoding interleukins (e.g. IL-1, IL-8, and IL-6) when they interact with the superficial layers of pocket epithelium (2). These pro-inflammatory cytokines have biological activities in immunoregulation and inflammation (4). However, elevated levels of these pro-inflammatory cytokines may exert deleterious effects on the integrity of subgingival tissues. For example, prolong secretion of IL-6 in response to invading bacteria may induce alveolar bone loss in chronic periodontitis patients (5). Matrix metalloproteinase (MMP) is another important host factor involved in periodontal diseases. MMP comprise a large family of endopeptidases that are responsible for remodeling and degradation of collagen and extracellular matrix of periodontal tissue including collagens, gelatin, elastin, matrix glycoprotein, and proteoglycans (6). In health condition, the activities of MMP are usually balanced by an endogenous inhibitor named tissue inhibitor of metalloproteinase (TIMP) (7). Imbalance between TIMP and MMP levels within periodontal tissue plays a pivotal role in the progression of periodontal diseases (8). Periodontal treatment aimed mainly towards removal of bacterial stimuli, which is reflected by downregulation of several inflammatory genes (9). Prolonged exposure to inflammatory cytokines is potentially associated with loss of epithelial-phenotype (10) such as IL-6, IL-1 $\beta$, IL-8, MMP-8, and TIMP-1 $(11,12)$. 
Nevertheless, initiation and progression of periodontal disease, even the response to periodontal treatment, is a complex multifactorial process, which is regulated by genetic and environmental factors (13). Inflammatory process in response to the presence of bacteria is not sufficient to cause periodontal disease unless associated with secretion of high level of inflammatory cytokines that further aggravated by aberrant immune response $(1,14)$. Recent data, from different in vitro models, suggest that epithelial tissue regain its phenotype within 3 days following removal of stimulus $(15,16)$. In addition, the inflammation moves into late stage, within 3 days, where the level of polypeptide mediators is upregulated targeting cells essential in healing process (17).

Limited data are available about the course of periodontal tissue healing at molecular level following withdrawal of bacterial stimulation. Our null hypothesis stated that epithelial integrity and level of inflammatory mediators would be restored to normal shortly after removal of bacterial stimulation. Thus, this study aimed to chronologically track the homeostasis of oral keratinocytes following withdrawal of periodontal pathogens, by investigating expression of selected inflammatory markers and integrity of epithelium in vitro.

\section{Material and Methods}

Culturing and Heat Killing Of Periodontal Pathogens

Two pathogenic periodontal bacteria were selected $F$. nucleatum (ATCC 10953) and P. gingivalis (ATCC 33277) (ATCC, Rockville, MD, USA) for this study. Bacteria were anaerobically cultured $\left(37{ }^{\circ} \mathrm{C}\right.$ in atmosphere of $80 \%$ Nitrogen, 10\% Carbon dioxide, and 10\% hydrogen) on plates of trypticase Soy Agar (Difco laboratories, Detroit, $\mathrm{MI}$, USA) supplemented with 5\% horse blood. After 3 days, colonies with identical morphology were incubated for 24 $\mathrm{h}$ in trypticase soy broth (Difco laboratories) at the same previous culturing condition. Then bacterial cell pellet was obtained by centrifuging at $4000 \mathrm{rpm}$ for $8 \mathrm{~min}$ and was heat-killed by autoclaving. Spectrophotometer (Jenway, Dunmow, UK) was used to determine concentration of bacteria in the suspension via measuring the optical density (OD) at $600 \mathrm{~nm}$. Validity of heat-killing procedure of the bacteria in the final suspension, containing $1 \times 10^{9}$ bacteria/ $\mathrm{ml}$, was checked by re-platting $50 \mu \mathrm{L}$ of the suspension on a blood agar and re-cultured anaerobically for $48 \mathrm{~h}$.

\section{Primary Rat Oral Keratinocytes Culture}

Culturing of primary oral keratinocytes started with excision of mandibular labial gingiva from carcass of Wistar Han rats (Charles River Laboratory, Kent, UK). Then gingival samples were placed in tube containing $4 \mathrm{ml}$ of $0.25 \%$ trypsin-EDTA (Sigma, Dorset, UK) at $4^{\circ} \mathrm{C}$ overnight.
In the next day, the epithelial sheet was teased away from the connective tissue by tweezer, dissected into smaller pieces and cultured in flask containing keratinocytes culture medium and Mitomycin-C (Sigma, Dorset, UK) inhibited 3T3 fibroblasts. Epithelial cells were incubated at $37^{\circ} \mathrm{C}$ in $5 \%$ Carbon dioxide until keratinocytes growth was identified by forming round colonies. The cells were subcultured after forming confluent monolayer. Each culture was stimulated with either medium only (negative control) or F. nucleatum and P. gingivalis (100 bacteria: epithelial cell to resemble the ratio of bacteria to epithelial cells in periodontal pocket) for 7 days. Supernatants of the cultures were collected and used later to assay cytokines level. Then epithelial cells were trypsinized and divided into two parts, one part used for polymerase chain reaction (PCR) and the other part was thoroughly washed three times with phosphate-buffered saline (PBS), to remove bacterial components, and re-cultured in new T25 flask (for 3 days) to investigate changes in the level of inflammatory markers following withdrawal of bacteria. Experiments were repeated in triplicate.

\section{Cell Count and Viability Assay}

Counting number of cells and percent of viable cells were estimated according to Trypan-blue (Sigma, Dorset, UK) method, where dead cells with disintegrated cell membrane appear blue in contrast to viable cells that remain unstained. Cell count and vitality of cultures stimulated with bacteria over 7 days were compared to unstimulated control.

\section{Assaying Protein Level of Interleukins}

Proteins level of IL-1 $\beta$, IL- 6 , and IL- 8 in the supernatants collected from oral keratinocytes cultures (unstimulated control, stimulated with bacteria and following removal of bacterial stimuli), were determined using ELISA kit (Thermo Fisher Scientific, Loughborough, UK) following manufacturer's manual. All assays repeated in triplicate.

\section{Semi-Quantitative Real Time Polymerase Chain Reaction}

RNA was harvested, utilizing RT lysis buffer (Qiagen, Manchester, UK), from unstimulated and stimulated cultures with periodontal pathogens following 7 days and at day 3 from stimulated cultures following withdrawal of bacterial stimulation. Total RNA $(1 \mu \mathrm{g})$ was then used to synthesize template of cDNA by using the Tetro kit (Bioline, London, UK) which was added to RedTaq ReadyMix (Sigma, Dorset, UK) that was amplified in thermal cycler (Mastercycler, Eppendorf, Germany) using primers (all supplied from Invitrogen, UK), for TIMP-1 (5'->3' F GCAGGGAAGAGAGAGGCAAA, RACAAGCTाTCCCGCTTGGA) 
and MMP-8 (5'->3' F GAGTGACATAGTGGCTGCTCA, R GTGTGACAAGGCTTAGGGGA), in a number of cycles ranging between 18 to 35. Each cycle started with denaturation for 5 min at $94^{\circ} \mathrm{C}$, then an amplification cycle at $94^{\circ} \mathrm{C}$ for $20 \mathrm{~s}$, followed by $60-61^{\circ} \mathrm{C}$ for $20 \mathrm{~s}$ and $72^{\circ} \mathrm{C}$ for $20 \mathrm{~s}$, cycle was ended by extension period for $10 \mathrm{~min}$ at $72^{\circ} \mathrm{C}$.

Products of Semi-quantitative real time polymerase chain reaction (Sq-RT-PCR) process were separated by electrophoresis in 1.5\% agarose gels containing ethidium bromide $(10 \mathrm{mg} / \mathrm{ml})$ (Sigma, Dorset, UK). Gels were placed in UV box and images captured by GeneSnap software (Syngene, Frederick, MD, USA). Analysis of these images was carried out using GeneTools software (Syngene, Frederick, MD, USA). All PCR products were normalized against the housekeeping gene GAPDH. Each experiment was run in triplicate.

\section{Transepithelial Electrical Resistance (TEER)}

Integrity of epithelial monolayer was investigated using TEER assay which is based on measuring the resistance of epithelial layer to the passage of an electric current as previously described (10).

\section{Statistical Analysis}

For statistical analysis for all experiments, normality test was conducted first to determine distribution of data. Due to nonparametric nature of data, the differences among and within time points for ELISA, PCR, and TEER experiments were calculated by Kruskal-Wallis test followed by Dunn's multiple comparison test. Results were considered statistically significant when $p<0.05$. SPSS software package, version 21 (IBM, USA) was used for conducting statistical analysis.

\section{Results}

\section{Cell Count and Viability}

Preliminary study was conducted first to investigate the effect of heat-killed bacteria on the vitality of oral keratinocytes. Results showed that there is no significant difference between cultures exposed to bacterial components and cultures treated with media only (Fig. $1 \mathrm{~A})$. In addition, cell count did not show any significant difference between unstimulated control and cell exposed to periodontal pathogens over 7-days (Fig. 1B).

\section{Expression of Inflammatory Mediators}

Exposure of primary oral keratinocytes to periodontal pathogens resulted in an increased secretion of inflammatory cytokines highly involved in periodontal disease. Fold increase in protein level in cultures stimulated with F. nucleatum and $P$. gingivalis ranged between 2-2.5, 5-6, and 5-7 for IL-1 $\beta$, IL-6, and IL-8 respectively as compared to unstimulated control. Withdrawal of bacterial stimulus from epithelial cultures resulted in downregulation of inflammatory cytokines measured. Level of IL-1 $\beta$ (Fig. $2 A, B$ ) and IL-6 (Fig. 2C,D) dropped to almost equal level to that of unstimulated control within three days after removal of bacterial stimulation (F. nucleatum and $P$. gingivalis). However, cultures treated with F. nucleatum failed to show similar pattern in association with IL-8 level which did not decrease in the same period even after withdrawal of stimulation (Fig. 2E). In contrast, cultures treated with $P$. gingivalis showed significant reduction of IL-8 after 2 days following removal of bacterial stimulation (Fig. 2F).

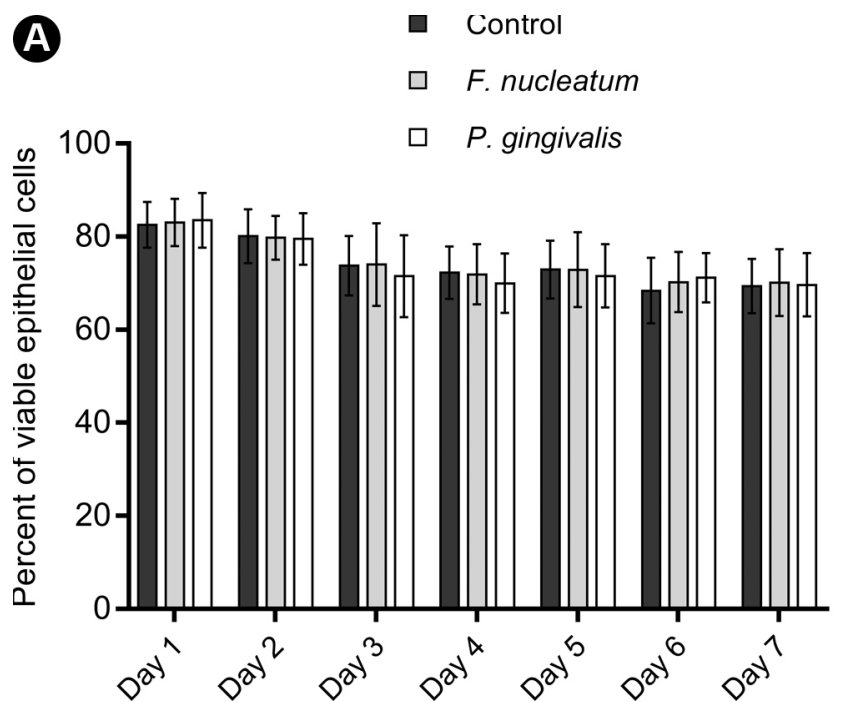

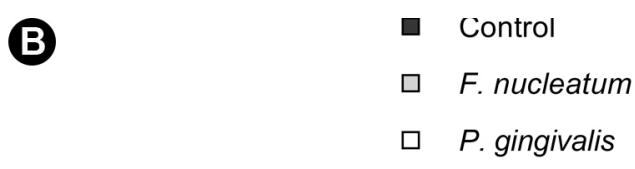

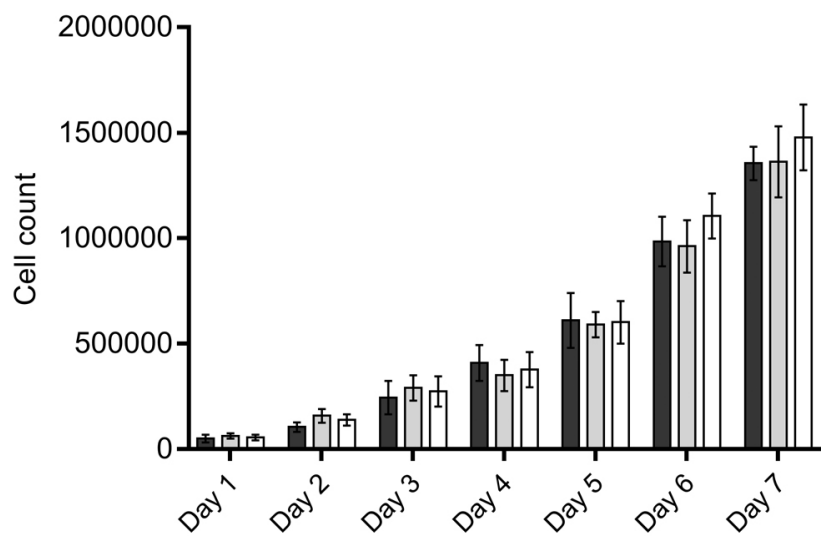

Figure 1 Vitality assay indicates that exposure of primary rat oral keratinocytes to periodontal pathogens (F. nucleatum and P. gingivalis) did not affect their vitality when compared to cultures treated with medium only (A). Growth curves of cells treated with media only and cells stimulated with bacteria did not show any significant different in cell count among all groups (B). 
A

$\square \quad$ Culturing for 7-days

ㄷ Control

口 Post-withdrawal of F. nucleatum

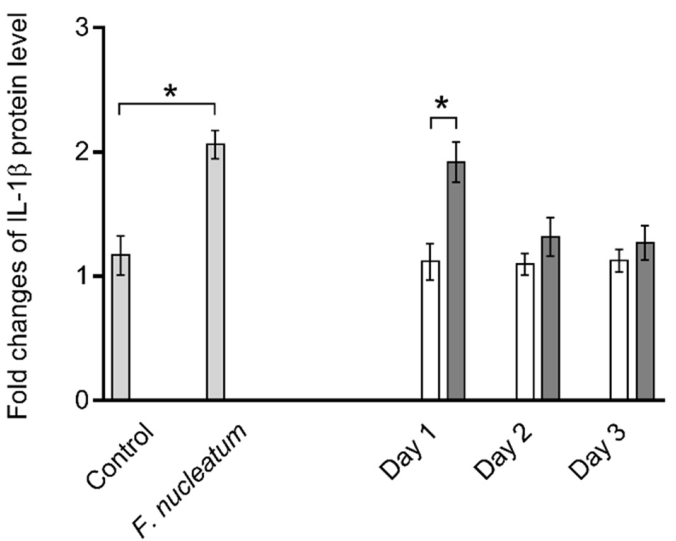

C

$\square \quad$ Culturing for 7-days

$\square \quad$ Legend

Post-withdrawal of $F$. nucleatum
B
$\square \quad$ Culturing for 7-days
Control
Post-withdrawal of $P$. gingivalis

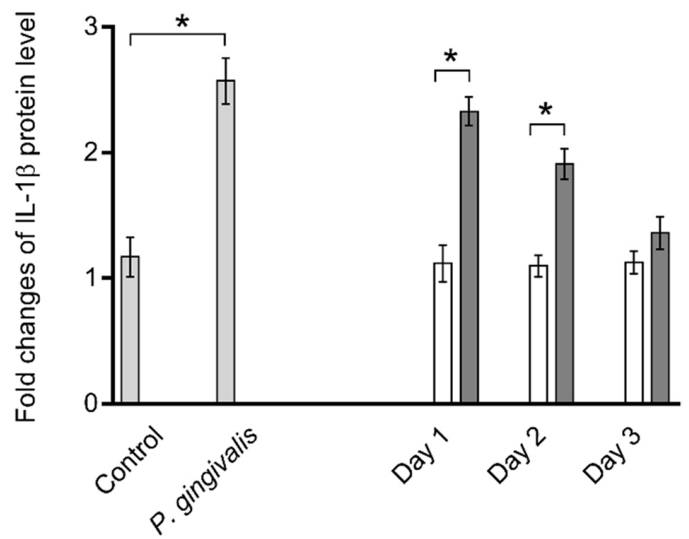

$\begin{array}{rll}\text { D } & \square & \text { Culturing for 7-days } \\ \square & \text { Legend } \\ \square & \text { Post-withdrawal of } P \text {. gingivalis }\end{array}$

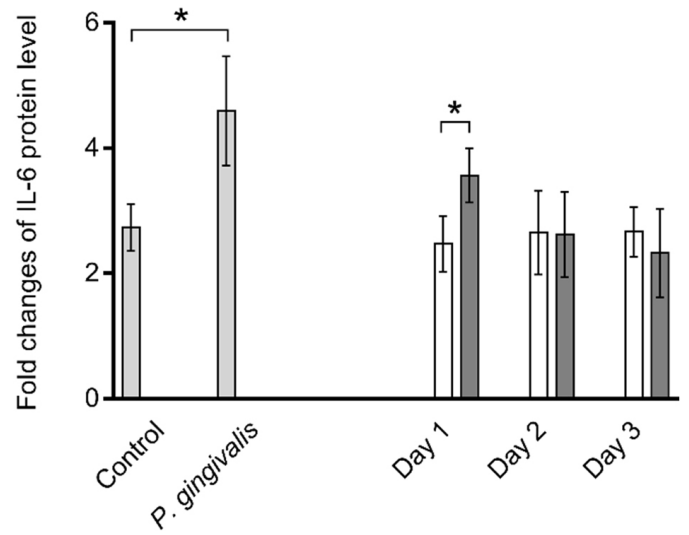

$\begin{array}{rll}\square \quad & \text { Culturing for 7-days } \\ \square & \text { Control } \\ \square & \text { Post-withdrawal of } P \text {. gingivalis }\end{array}$

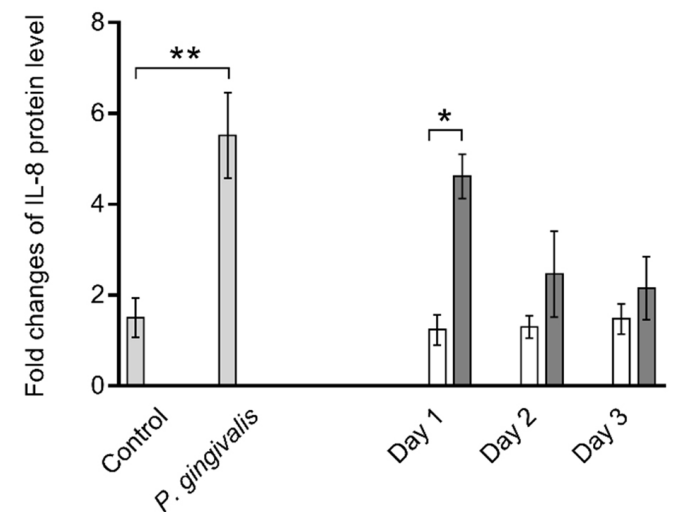

Figure 2 ELISA assay of supernatant collected from oral epithelial cells cultures during and after removal of bacterial stimulation showed decreased expression of IL- $1 \beta$ to almost equal level to that of unstimulated control after 2 days in association with $F$. nucleatum (A). While level of IL- $1 \beta$ in cultures treated with $P$. gingivalis (B), required 3 days to restore the same level of unstimulated control. Withdrawal of $F$. nucleatum (C) and $P$. gingivalis (D) resulted in downregulation of IL-6 protein level to that of unstimulated control after 3 and 2 days respectively. While removal of F. nucleatum from oral epithelial cultures did not affect the level of IL-8, which showed sustained elevated level in comparison to unstimulated control over experimental period (E). In contrast, cells treated with $P$. gingivalis (F) restored normal level of IL-8, as compared to control, after removal of bacteria from cultures. Data were obtained from triplicate experiment. ${ }^{*}=\mathrm{p} \leq 0.05,{ }^{* *}=\mathrm{p} \leq 0.00$. 
Treatment of epithelial cultures with heat-inactivated periodontal pathogens, F. nucleatum and P. gingivalis, over 7 days caused changes in transcription of two markers widely recognized in pathogenesis of periodontitis. Both bacteria utilised in this study reduced expression of TIMP-1 which is a well-known protein for its activity in regulating physiological tissue remodelling through modulating action of MMP. PCR data showed that $F$. nucleatum and P. gingivalis downregulated expression of TIMP-1 by about 4-fold during stimulation period when compared to unstimulated control. Following washing out bacterial stimuli, TIMP-1 regains its normal level within 3 days as demonstrated in densitometric analysis of samples (Fig. $3 A, B)$. Transcriptional level of MMP-8 was upregulated up to 4-fold in association with F. nucleatum while $P$. gingivalis resulted in higher upregulation ( 7 -fold) in comparison to unstimulated control. Expression of MMP-8 reduced to same level of unstimulated cultures following removal of $F$. nucleatum stimulation (Fig. 3C). In contrast, transcription of MMP-8 in cultures treated with $P$. gingivalis remain significantly higher than control group even after removal of bacteria from epithelial cell cultures (Fig. 3D).
(4)

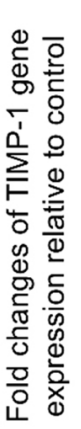

C

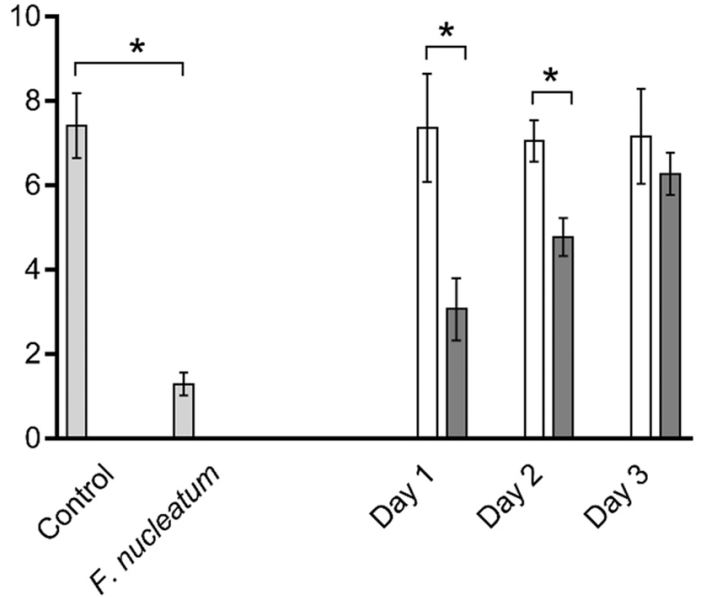

C

$\begin{array}{ll}\square & \text { Culturing for 7-days } \\ \square & \text { Control } \\ \square & \text { Post-withdrawal of } F \text {. nucleatum }\end{array}$
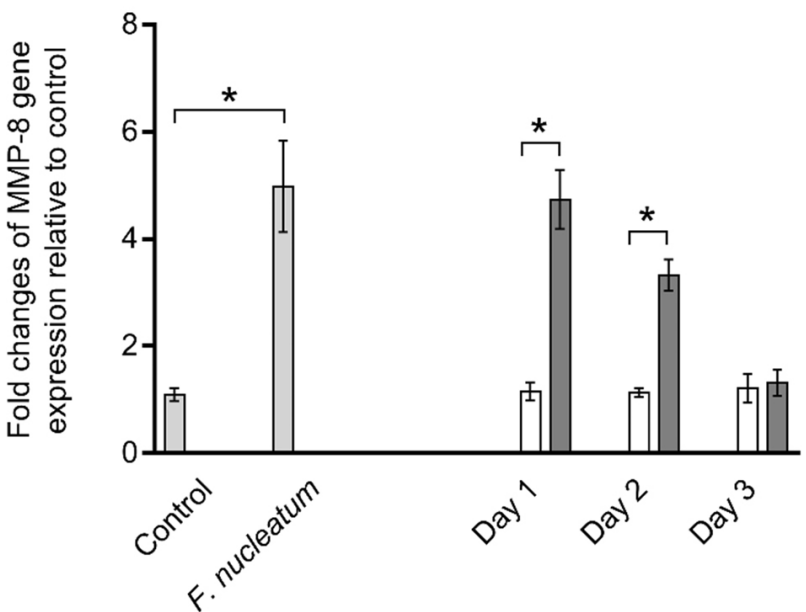

B
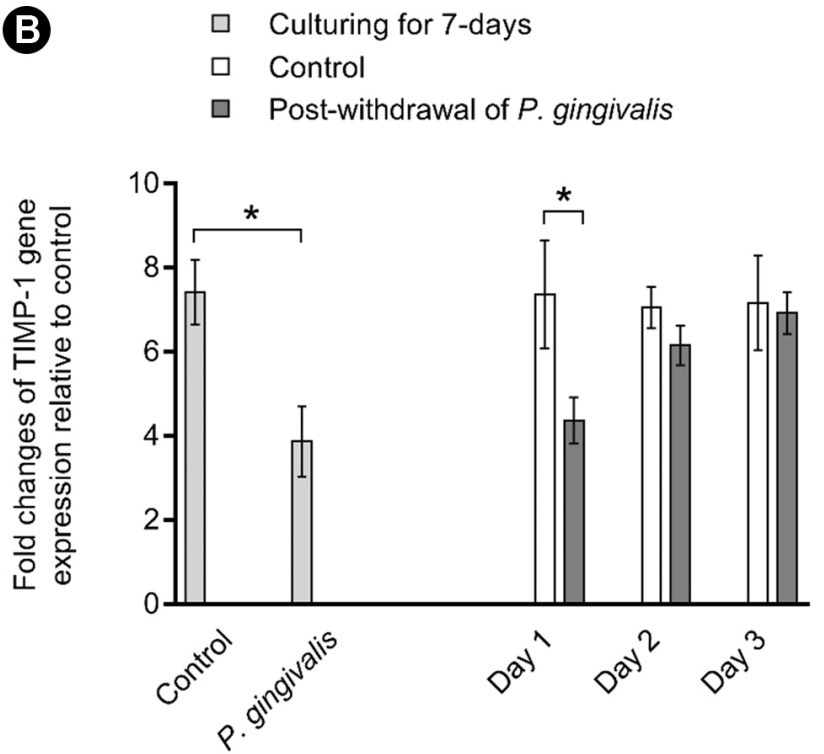

D
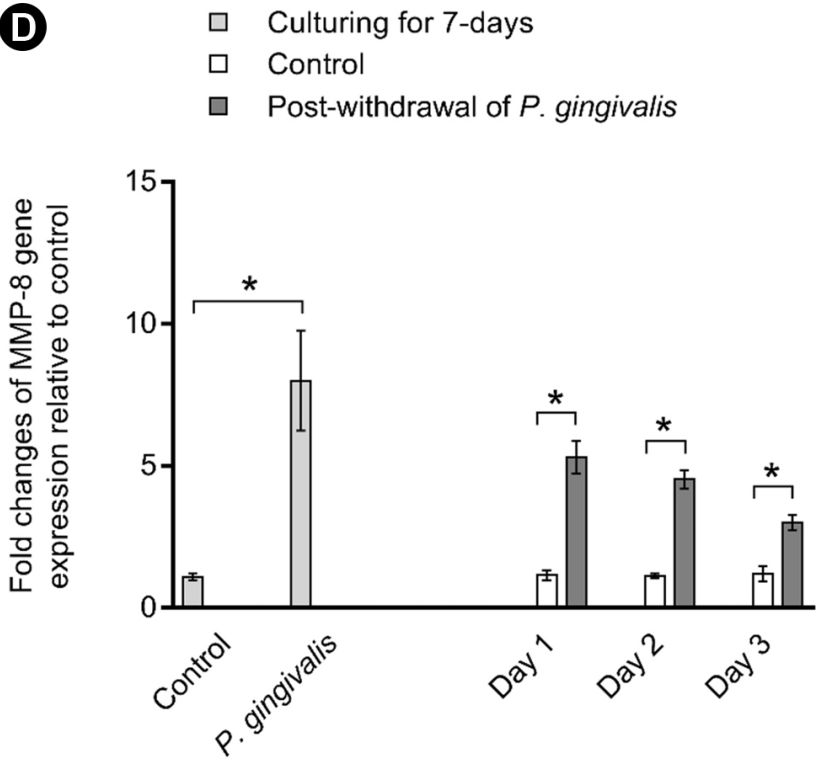

Figure 3 Densitometric analysis shows upregulation of TIMP-1 (A, B) following removal of $F$. nucleatum and P. gingivalis after 3- and 2- days respectively in comparison with control. Expression of MMP-8 (C, D) showed similar pattern in which withdrawal of F. nucleatum resulted in downregulation of this enzyme to almost same level of cultures treated with medium only. However, MMP-8 level remained significantly higher, over 3-days, than unstimulated control even after removal of $P$. gingivalis from oral keratinocytes cultures. Experiments were repeated in triplicate. ${ }^{*}=\mathrm{p} \leq 0.05$. 


\section{Integrity of Epithelial Monolayer}

The coherence of epithelial cultures was investigated by using TEER experiment. Exposure of epithelial cultures to both bacteria resulted in decrease their resistance to the passage of electric current. Resistance of epithelial layer gradually increased following removal of $F$. nucleatum from cultures starting from day 2 (Fig. 4A). Nevertheless, integrity of epithelial layer remained compromised even after removal of $P$. gingivalis from epithelial cultures in which TEER measurements were significantly lower $(p<0.05)$ than control over experimental period (Fig. 4B).

\section{Discussion}

Sequelae of periodontal disease is essentially dependent on the interaction between dental biofilm and host immune response (1). Inflammatory response is an integral aspect of defense mechanism; however, it could lead to unavoidable collateral damage to the supporting periodontal tissues mainly due to excessive secretion of inflammatory cytokines (18). Epithelial pocket lining is the first line of defense in which the coherence of epithelial cells represents a physical barrier against invading microorganisms. In addition, epithelial cells sense the presence of bacteria by special receptors and subsequently response by secreting range of inflammatory mediators $(2,19)$ directly proportional to the severity of inflammation $(20,21)$. Previous studies mainly focused on comparing histological and pathological aspects of periodontal disease relative to healthy control (22). However, timeline tracking of molecular changes in

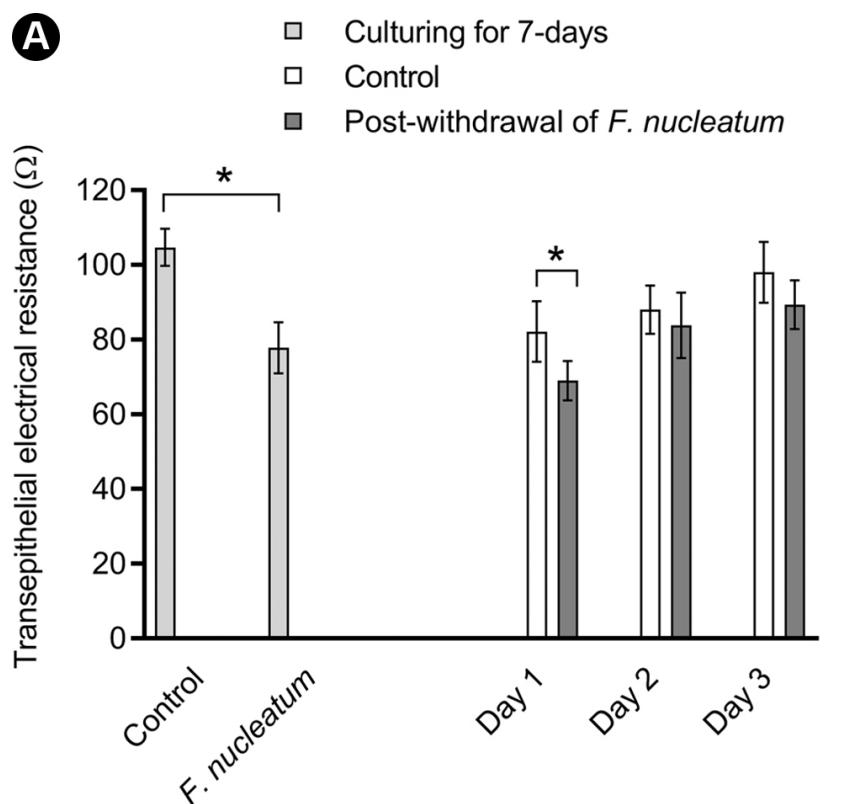

primary oral epithelial cells before and after removal of bacterial stimulation received limited attention. Current study chronologically explored homeostasis of oral epithelial cells following removal of bacterial stimuli, over 3-days. This was performed by monitoring integrity of epithelial monolayer and the expression of selected inflammatory cytokines.

Prolonged exposure to inflammatory cytokines potentially lead to loss of epithelial-phenotype and hence loss of epithelial barrier function (10), which subsequently facilitate invasion of pathogenic periodontal bacteria to deeper connective tissues. Fortunately, this cellular event is reversible upon removal of the stimuli. Many in vitro studies suggested different time intervals for epithelial cells to regain their original phenotype; however, an average period of three days was shown to be sufficient for phenotype reprogramming process $(15,16)$. Since no similar studies about homeostasis of primary oral keratinocytes were available; thus, this period was selected in our study. In addition, majority of other studies either utilized cancer cell line or primary epithelial cells from other organs rather than oral epithelium. It is well known that Gram-negative anaerobic pathogens are mostly associated with the destructive phase of periodontal disease, as these bacteria possess range of virulence factors responsible for triggering intense-immune response (23). For this reason, two wellrecognized pathogenic periodontal bacteria, F. nucleatum and P. gingivalis, were heat-killed and used to stimulate oral epithelial cultures in current study. Although viable
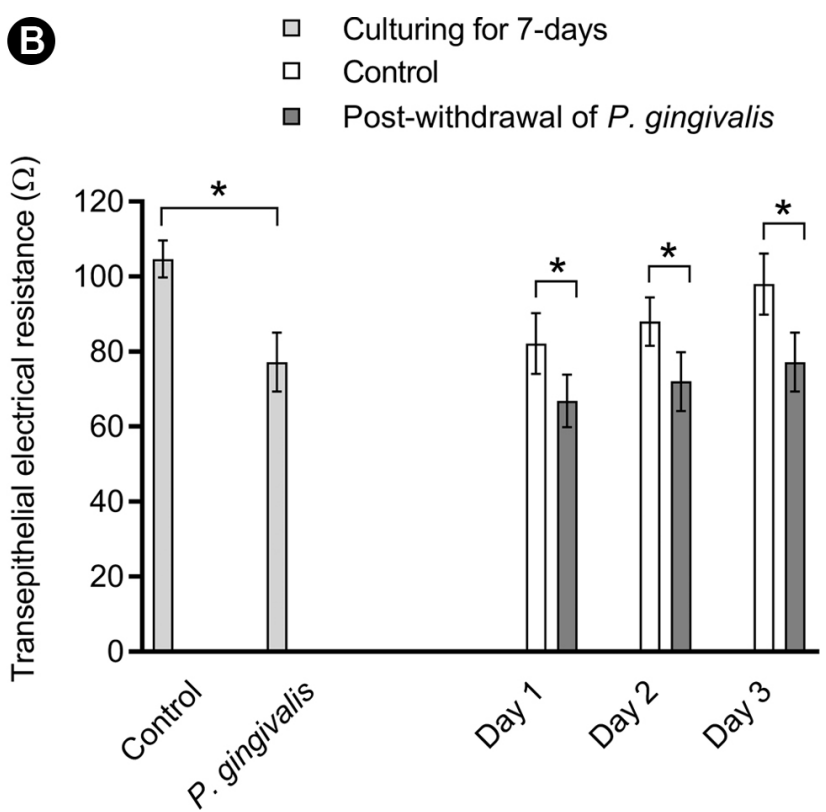

Figure 4 (A) Resistance to the passage of an electric current was gradually increased to normal in association with $F$. nucleatum starting from day 2. However, resistance to the passage of the electric current remain significantly lower than unstimulated control even after removal of $P$. gingivalis from epithelial cultures (B). Experiment was repeated in triplicate. ${ }^{*}=\mathrm{p} \leq 0.05$. 
bacteria could better represent in vivo situation; however, dental biofilm harbours both viable and dead bacteria together with their virulence factors. Further, dead bacteria are safer and technically easier to manipulate as compared to living bacteria. Following exposure of epithelial cells to bacteria over 7 days, cultures were thoroughly washed with PBS and re-cultured in new flask to ensure that bacterial stimuli were removed in an attempt to mimic mechanical debridement of periodontal pocket in vivo. Data showed general downregulation in protein level of IL-1 $\beta$, and IL-6 to normal level after 2-3 days following removal of $F$. nucleatum and $P$. gingivalis from epithelial cells cultures. IL-8 level was only downregulated in association with clearance of $P$. gingivalis from cultures which is consistent with findings from previous study which indicated that expression of inflammatory genes restored to healthy status following removal of dental biofilm (9). In contrast, cells stimulated with F. nucleatum showed sustained elevation of IL-8 secretion even after removal of bacterial stimuli from epithelial cells culture. This potentially indicates difference in severity of inflammatory response associated with different bacteria in which certain periodontal pathogens may cause longer-standing inflammation and hence more damage to periodontal tissues. This difference in expression of inflammatory cytokines could be due to difference in the potency of virulence factors derived from different periodontal pathogens. This notion is supported by results from previous studies which indicated presence of difference in the structure and potency in lipopolysaccharide (LPS), in different bacteria (24), that could trigger different inflammatory cascades. Furthermore, Martinho and coworkers (24), showed that LPS isolated from F. nucleatum induced higher expression of inflammatory cytokines in comparison to P. gingivalis. Analysis of PCR data showed increased transcription of proteolytic enzyme, MMP-8, in association with both bacteria utilized in this study which is consistent with previous study which concluded that $F$. nucleatum and $P$. gingivalis are potent inducers of MMP-8 (25). Again, expression of MMP-8 showed similar pattern to that of IL-8 in which epithelial cultures treated with $P$. gingivalis continued to express high transcriptional level of MMP-8, relative to unstimulated control, even after removal of bacterial stimuli. This could be attributed to differences in signaling downstream that may lead to persistent expression of inflammation-associated genes by certain periodontal pathogens. Destruction of periodontal tissues requires not only increased secretion of MMP enzymes but also inhibition of regulatory protein (TIMP-1) that plays an important role in modulating action of these enzymes (8). Consistently, results from current study showed significant downregulation of TIMP-1 in response to bacterial stimulation and its level restored to normal following withdrawal of $F$. nucleatum and $P$. gingivalis from oral keratinocytes cultures. Integrity of epithelial monolayers following exposure to stimuli was investigated by utilising TEER technique. The principle of this assay is dependent on measuring the resistance to the passage of an electric current through epithelial layer. Loss of epithelial barrier integrity is detected by the decrease in its impedance to the passage of the electric current, due to increase intercellular spaces compared to intact epithelial layer which shows higher resistance. Prolonged loss of integrity was evident in association with $P$. gingivalis which continued over 3 days. In contrast, epithelial integrity was restored following removal of $F$. nucleatum from the cultures. This could be linked to the a previous finding of this study in which P. gingivalis was associated with higher expression of MMP-8 that could interfere with restoring coherence of the epithelium.

Current study requires further improvements such as the use of clinical strains, isolated from dental plaque samples, of targeted bacteria over longer period. Further, the use of viable bacteria to infect the epithelial cells would generate more realistic results than heat-killed bacteria. In addition, monitoring other inflammatory indicators highly associated with inflammatory response of periodontal tissues such as IL-10 and TNF- $\alpha$ over longer periods is required.

Within limits of this study, it can be concluded that stimulation of oral keratinocytes by periodontal pathogens may lead to persistent upregulation of inflammatory mediators, even after removal of bacteria that could interfere with homeostasis of periodontal tissues. In addition, data of this study also highlighted differential expression of different inflammatory markers in response to bacterial stimuli. These results rejected the stated null hypothesis. Therefore, further investigations are required to pinpoint inflammatory markers potentially involved in progression towards non-resolving periodontal lesion in susceptible individuals.

\section{Resumo}

A inflamação dos tecidos periodontais é a consequência da interação entre patógenos periodontais e o sistema imunológico. Isso está associado ao aumento da expressão de citocinas inflamatórias, que podem exercer efeito destrutivo nos tecidos periodontais quando liberadas por um longo período. 0 objetivo deste estudo foi rastrear cronologicamente a homeostase dos queratinócitos orais após a remoção dos patógenos periodontais. Isto foi feito através da investigação da expressão de marcadores inflamatórios selecionados e da integridade de monocamadas epiteliais in vitro. Os queratinócitos orais de rato foram estimulados com Fusobacterium nucleatum e Porphyromonas gingivalis destruidas pelo calor por 7 dias, depois as bactérias foram lavadas e as células epiteliais foram cultivadas novamente por 3 dias. A expressão de IL-1 $\beta$, IL-6 e IL-8 foi medida por ELISA, enquanto a transcrição do inibidor tecidual de metaloproteinase-1 (TIMP-1) e matriz metalopeptidase-8 (MMP-8) foi medida por reação em cadeia da polimerase antes e após a remoção de bactérias. A integridade da folha epitelial foi investigada usando resistência elétrica transepitelial. Os dados mostraram uma regulação negativa geral de IL-1 $\beta$, IL-6 e IL-8 
associada à restauração da transcrição de TIMP-1 e MMP-8 para o nível normal após a remoção de bactérias de culturas epiteliais. No entanto, a expressão de IL-8 e MMP-8 permaneceu significativamente maior que as células epiteliais não estimuladas, apesar da retirada de $F$. nucleatum e $P$. gingivalis, respectivamente, das culturas de queratinócitos orais. Além disso, a integridade da função da barreira epitelial permaneceu comprometida mesmo após a remoção de $P$. gingivalis. Os resultados sugerem que, mesmo após três dias após a remoção dos patógenos periodontais, os queratinócitos orais sustentaram uma regulação positiva persistente de certos marcadores inflamatórios que poderiam comprometer a integridade da função da barreira epitelial.

\section{Acknowledgements}

This research was funded by University of Baghdad/ Iraqi Ministry of Higher Education and Scientific research.

\section{References}

1. Tribble GD, Lamont RJ. Bacterial invasion of epithelial cells and spreading in periodontal tissue. Periodontol 2000 2010;52:68-83.

2. Stathopoulou PG, Benakanakere MR, Galicia JC, Kinane DF. Epithelial cell pro-inflammatory cytokine response differs across dental plaque bacterial species. J Clin Periodontol 2010;37:24-29.

3. How KY, Song KP, Chan KGJFim. P. gingivalis: an overview of periodontopathic pathogen below the gum line. Front Microbiol 2016;7:53.

4. Kinane DF, Galicia JC, Gorr S-U, Stathopoulou PG, Benakanakere M. P. gingivalis interactions with epithelial cells. Front Biosci 2008;13:966984.

5. Takahashi K, Takashiba S, Nagai A, Takigawa M, Myoukai F, Kurihara H, et al. Assessment of interleukin- 6 in the pathogenesis of periodontal disease. J Periodontol 1994;65:147-153.

6. Sapna G, Gokul S, Bagri-Manjrekar K. Matrix metalloproteinases and periodontal diseases. Oral Dis 2014;20:538-550.

7. Arpino $V$, Brock $M$, Gill SE. The role of TIMPs in regulation of extracellular matrix proteolysis. Matrix Biol 2015;44:247-254.

8. Verstappen J, Von den Hoff JW. Tissue inhibitors of metalloproteinases (TIMPS): their biological functions and involvement in oral disease. J Dent Res 2006;85:1074-1084.

9. Beikler T, Peters U, Prior K, Eisenacher M, Flemmig TF. Gene expression in periodontal tissues following treatment. BMC Med Genomics 2008; $1: 30$

10. Abdulkareem A, Shelton R, Landini G, Cooper P, Milward M. Potential role of periodontal pathogens in compromising epithelial barrier function by inducing epithelial-mesenchymal transition. J Periodontal Res 2018;53:565-574.

11. D'Angelo RC, Liu X-W, Najy AJ, Jung YS, Won J, Chai KX, et al. TIMP-1 via TWIST1 induces EMT phenotypes in human breast epithelial cells. Mol Cancer Res 2014;12:1324-1333.

12. Chockley PJ, Keshamouni VG. Immunological consequences of epithelial-mesenchymal transition in tumor progression. J Immunol 2016;197:691-698.
13. Martínez $A B$, Corcuera $M M$, Noronha $S$, Mota $P$, llundain $C B$, Trapero JC. Host defence mechanisms against bacterial aggression in periodontal disease: basic mechanisms. Med Oral Patol Oral Cir Bucal 2009;14:13.

14. Feng $Z$, Weinberg A. Role of bacteria in health and disease of periodontal tissues. Periodontol 2000 2006;40:50-76.

15. Hansson J, Rafiee MR, Reiland S, Polo JM, Gehring J, Okawa S, et al. Highly coordinated proteome dynamics during reprogramming of somatic cells to pluripotency. Cell Rep 2012;2:1579-1592.

16. Shu X, Pei D. The function and regulation of mesenchymal-to-epithelial transition in somatic cell reprogramming. Curr Opin Genet Dev 2014;28:32-37.

17. Polimeni G, Xiropaidis AV, Wikesjö UME. Biology and principles of periodontal wound healing/regeneration. Periodontol 2000 2006;41:30-47.

18. Watanabe K, lizuka $T$, Adeleke A, Pham L, Shlimon A, Yasin M, et al. Involvement of toll-like receptor 4 in alveolar bone loss and glucose homeostasis in experimental periodontitis. J Periodontol Res 2011;46:21-30

19. Andrian E, Grenier D, Rouabhia M. Porphyromonas gingivalis-epithelial cell interactions in periodontitis. J Dent Res 2006;85:392-403.

20. Zhu H, Lin $X$, Zheng $P_{\text {, Chen }}$. Inflammatory cytokine levels in patients with periodontitis and/or coronary heart disease. Int J Clin Exp Pathol 2015;8:2214

21. Tâlvan ET, Mohor C, Chisnoiu D, Cristea V, Câmpian RS. Expression of interleukin (IL)-1 $\beta$, IL-8, IL-10 and IL-13 in chronic adult periodontitis progression. Arch Med 2017;9.

22. Smith M, Seymour GJ, Cullinan MP. Histopathological features of chronic and aggressive periodontitis. Periodontol 2000 2010;53:45-54.

23. Abiko Y, Sato T, Mayanagi G, Takahashi N. Profiling of subgingival plaque biofilm microflora from periodontally healthy subjects and from subjects with periodontitis using quantitative real-time PCR. J Periodontol Res 2010;45:389-395.

24. Martinho FC, Leite FR, Nóbrega LM, Endo MS, Nascimento GG, Darveau $\mathrm{RP}$, et al. Comparison of Fusobacterium nucleatum and Porphyromonas gingivalis lipopolysaccharides clinically isolated from root canal infection in the induction of pro-inflammatory cytokines secretion. Braz Dent J 2016;27:202-207.

25. Holla LI, Hrdlickova B, Vokurka J, Fassmann A. Matrix metalloproteinase 8 (MMP8) gene polymorphisms in chronic periodontitis. Arch Oral Biol 2012;57:188-196.
Received May 11, 2019

Accepted November 25, 2019 